\title{
Ordo Dei - Inspirations by the Thought of Blessed John Paul II (Będzin, 26 November 2011)
}

On November 26, 2011 in St. Joseph's House in Będzin an all-Polish conference Ordo Dei Inspirations by the Thought of Blessed John Paul II was held. The conference, under the honorary auspices of the bishop of Sosnowiec Diocese Grzegorz Kaszak Ph.D., was organised by the Institute of Catechetics, Christian Pedagogics and Catholic Social Teaching of the Department of Theology at the University of Silesia and the Catholic Action Institute in Sosnowiec Diocese.

The conference was formally opened by the chairman of the Catholic Action Jan Maizner Ph.D. who welcomed all the speakers and guests, informed about the aims of the meeting and presented the programme of the conference.

Introduction was offered by bishop Grzegorz Kaszak Ph.D.. Alluding to social and cultural changes of the contemporary world he suggested that today it is not easy to talk about an order of thought and heart, requirements, rules and norms, about everything that obliges our conscience which is a reflection of God's order. It is not rare that not only basic rules of a social life are ignored, but also values that protect human life from the flaw of consumerism and a practical materialism. In this context thoughts of John Paul II are exceptionally precious for us. Teaching of this great advocate of God's order in the world of thought and deed is a treasury for the Church from which we must draw abundantly and share with others.

The first speaker was Professor Jan Związek (Jan Długosz Academy, Częstochowa), who gave a lecture entitled "Seminary in Częstochowa in statements of blessed John Paul II". In a broad historic perspective the priest returned, first of all, to the person of bishop Teodor Kubina, the builder and organiser of the Częstochowa Seminary in Kraków. Further on numerous encounters with the professor and a metropolitan Karol Wojtyła in Częstochowa Seminary were indicated. Professor Związek provided his listeners with the pope's statements concerning the Częstochowa Seminary. The most important 
ones were uttered during the visits of John Paul II in his homeland, when he met professors and students of the Częstochowa Seminary on his pilgrim's path.

The next paper entitled "Thoughts of blessed John Paul II on his homeland as an inspiration for bringing up to patriotism" was presented by father Roman Buchta Ph.D. (Department of Theology, University of Silesia - Katowice). Alluding to the Week of Upbringing held for the first time in September 2011 he evoked the call of Polish bishops to the faithful in a pastoral letter "Let us all start bringing up". An underlined duty of a common care for the future fate of the nation concerns various aspects of upbringing. One of them is upbringing to patriotism. It goes in line with the educational mission of the Church which is executed in teaching catechesis at school, in upbringing in a family and a parish catechesis. A dynamic process of globalisation and a European integration often contributes not only to a lack of understanding of a traditionally understood patriotism, but also to its total rejection. In this context an exceptional source of inspiration for upbringing are thoughts of John Paul II on Polish history, respect for the homeland and a need to protect and keep a national identity.

The last speaker of this part of the conference was Tomasz Żukowski Ph. D. (University of Warsaw - Warszawa) who presented a paper entitled "JP2 society? Contemporary Poles and a heritage of John Paul II". Referring to the results of a sociological survey Żukowski Ph.D. commented upon social and religious approaches declared in questionnaires by the surveyed respondents. In the context of current transformations one can observe certain changes in the approach of Poles towards the issue of religion, Christian morality and the Catholic church viewed as an institution. In comparison to the results of a survey in other European countries Poles still, to a large extent, declare their attachment to traditional values such as faith, family and homeland. Therefore speaking of "JP2 society" is not deprived of scientific bases.

After a break the speaker was father Marian Szymonik Ph.D. (Higher Institute of Theology - Częstochowa). His paper was entitled "Axiological foundations of culture as presented by blessed John Paul II". Referring to a complex situation of a contemporary social life he drew listeners' attention to the fact that an interpretative key to describe processes that go on in the society is currently looked for. In the speaker's opinion this key to interpret many social and cultural processes is to be found in the academic works of John Paul II. In the first part of the paper father Szymonik referred to a dispute concerning the shape of a social and cultural life which as a matter of fact is a dispute concerning understanding of a human person. In this context it was reminded that John Paul II always underlined the fact that the subject of culture, its proper foundation, is a human 
person understood in an integral entirety of his spiritual-and-material structure. This balance between a spirit and matter is a basis od a correct understanding of a human person and a culture. The second part of the paper was devoted to an axiology of major fields of culture and a role of Christianity in a public discourse of the contemporary Europe. Alluding to the thought of John Paul II it was underlined that it is Christianity that is the strongest binder of Europe. All technical and administrative solutions aiming at a unification of Europe are secondary to a cultural and religious elements. Therefore the pope's words, uttered by him many times during his pontificate, ring out even louder: "Do not be afraid. Open wide the doors for Christ!".

The last speaker was an organiser of the meeting father Grzegorz Noszczyk Ph. D. (Department of Theology, University of Silesia - Katowice) who presented his paper entitled "In search of the nature of solidarity". As father Noszczyk observed the Church always underlined the value of a human person in a consistent and uncompromising way. The Church is aware of the fact that although it was called to mediate in the redemptive work of Jesus Christ, this soteriological process starts already during a man's existence on earth. This belief lies at the base of the Church's concern for both supernatural and worldly life of a man. This concern for the earthly world is not a transgression of the Church's authorities, but a service for a man. Expression of this attitude is a genuine programme incorporated in the idea of an interpersonal solidarity. Reflection of John Paul II is strongly embedded in the Church's teaching on solidarity. A special occasion which in a sense obliges us to study once again the pope's social teaching is the 20th anniversary of announcing the encyclical "Sollicitudo rei socialis".

A discussion included in the programme of the conference gave its participants a possibility to ask the speakers questions and exchange creative ideas. The conference was also a chance to initiate closer academic contacts and make common plans related to operations of the Catholic Action in the diocese. The meeting was concluded by Jan Maizer Ph.D. He thanked the lecturers, invited guests and all the participants. Also, he expressed a wish according to which the thought of blessed John Paul II should pervade our everyday life more and more. In this way the world we live in will become a more perfect reflection of Ordo Dei. 
